\title{
Neonatal Activation of CD28 Signaling Overcomes T Cell Anergy and Prevents Autoimmune Diabetes by an IL-4-dependent Mechanism
}

\author{
Guillermo A. Arreaza, ${ }^{\star}$ Mark J. Cameron, ${ }^{\star \ddagger}$ Andrés Jaramillo, ${ }^{*}$ Bruce M. Gill, ${ }^{\star}$ Dan Hardy, ${ }^{\star}$ Kevin B. Laupland, ${ }^{\star}$ \\ Micha J. Rapoport, ${ }^{\star}$ Peter Zucker, ${ }^{\star}$ Subrata Chakrabarti, ${ }^{\S}$ Stephen W. Chensue,, Hui-Yu Qin, ${ }^{\ddagger}$ Bhagirath Singh, ${ }^{\ddagger}$ \\ and Terry L. Delovitch* \\ *Autoimmunity/Diabetes Group, The John P. Robarts Research Institute, London, Ontario N6G 2V4, Canada; ${ }^{\ddagger}$ Department of \\ Microbiology and Immunology, University of Western Ontario, London, Ontario N6A 5C1, Canada; ${ }^{\S}$ Department of Pathology,

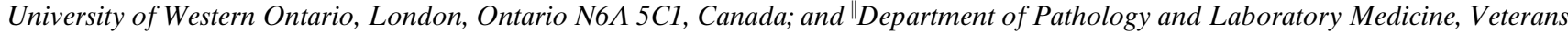 \\ Affairs Medical Center University of Michigan, Ann Arbor, Michigan 48105
}

\begin{abstract}
Optimal $T$ cell responsiveness requires signaling through the $T$ cell receptor (TCR) and CD28 costimulatory receptors. Previously, we showed that $\mathrm{T}$ cells from autoimmune nonobese diabetic (NOD) mice display proliferative hyporesponsiveness to TCR stimulation, which may be causal to the development of insulin-dependent diabetes mellitus (IDDM). Here, we demonstrate that anti-CD28 mAb stimulation restores complete NOD $\mathrm{T}$ cell proliferative responsiveness by augmentation of IL-4 production. Whereas neonatal treatment of NOD mice with anti-CD28 beginning at 2 wk of age inhibits destructive insulitis and protects against IDDM by enhancement of IL-4 production by islet-infiltrating T cells, administration of anti-CD28 beginning at 5-6 wk of age does not prevent IDDM. Simultaneous anti-IL-4 treatment abrogates the preventative effect of anti-CD28 treatment. Thus, neonatal CD28 costimulation during 2-4 wk of age is required to prevent IDDM, and is mediated by the generation of a Th2 cell-enriched nondestructive environment in the pancreatic islets of treated NOD mice. Our data support the hypothesis that a CD28 signal is requisite for activation of IL-4-producing cells and protection from IDDM. ( $J$. Clin. Invest. 1997. 100:2243-2253.) Key words: diabetes mellitus - insulin dependent - mice, inbred NOD • islets of Langerhans • Th1 cells $\bullet$ Th 2 cells
\end{abstract}

\section{Introduction}

Insulin-dependent diabetes mellitus (IDDM) ${ }^{1}$ is a polygenic multifactorial autoimmune disease heralded by $\mathrm{T}$ cell infiltration of the pancreatic islets of Langerhans (insulitis) and progressive $\mathrm{T}$ cell-mediated destruction of insulin-producing $\beta$

The first two authors contributed equally to this paper.

Address correspondence to Terry L. Delovitch, Ph.D., Director, Autoimmunity/Diabetes Group, The John P. Robarts Research Institute, 1400 Western Road, London, Ontario N6G 2V4, Canada. Phone: 519-663-3972; FAX: 519-663-3847; E-mail: del@rri.on.ca

Received for publication 18 April 1997 and accepted in revised form 28 August 1997.

1. Abbreviations used in this paper: APC, antigen-presenting cell; BGL, blood glucose level; GAD, glutamic acid decarboxylase; IDDM, insulin-dependent diabetes mellitus; TCR, T cell receptor.

J. Clin. Invest.

(C) The American Society for Clinical Investigation, Inc. 0021-9738/97/11/2243/11 \$2.00

Volume 100, Number 9, November 1997, 2243-2253

http://www.jci.org cells (1-3). CD4 ${ }^{+} \mathrm{T}$ helper cells are required for the adoptive transfer of IDDM into recipient neonatal NOD mice or immunodeficient NOD.Scid mice (4-6). Cooperation between $\mathrm{CD}^{+}$and $\mathrm{CD}^{+} \mathrm{T}$ cells is required to initiate IDDM, and islet $\beta$ cell destruction is $\mathrm{CD}^{+} \mathrm{T}$ cell-dependent $(7,8)$. Current evidence suggests that the $\mathrm{CD} 4^{+}$effector cells of IDDM in NOD mice are Th1 cells that secrete IL- 2 , IFN- $\gamma$, and TNF- $\alpha$, and that the regulatory $\mathrm{CD} 4^{+}$cells are Th2 cells that secrete IL-4, IL-5, IL-6, IL-10, and IL-13 (9-11).

We previously discovered that, beginning at $3-5 \mathrm{wk}$ of age, $\mathrm{T}$ cell receptor (TCR) ligation induces proliferative hyporesponsiveness of NOD thymic and peripheral T cells, which is mediated by reduced IL-2 and IL-4 production (12-14). Decreased IL- 4 production by human T cells from patients with new-onset IDDM has also been demonstrated recently (15). Whereas addition of IL-4, a Th2-type cytokine, potentiates IL-2 production and completely restores NOD T cell proliferative responsiveness, addition of IL-2, a Th1-type cytokine, even at high concentrations, only partially restores NOD $\mathrm{T}$ cell responsiveness. These findings suggest that Th2 cells may be compromised in function to a greater extent than Th1 cells in NOD mice, and raise the possibility that $\mathrm{Th} 2$ cells require a higher threshold of activation than Th1 cells in these mice. IL-4 not only restores NOD T cell responsiveness in vitro, but prevents insulitis and IDDM when administered in vivo to prediabetic NOD mice (13) and when transgenically expressed in pancreatic $\beta$ cells (16). The proliferative hyporesponsiveness of regulatory Th 2 cells in NOD mice may favor a Th1 cell-mediated environment in the pancreas of these mice, and lead to a loss of immunological tolerance to islet $\beta$ cell autoantigens. This possibility is consistent with the notion that restoration of the balance between Th1 and Th2 cell function may prevent $\operatorname{IDDM}(9,10,17)$.

Optimal $\mathrm{T}$ cell activation requires signaling through the TCR and CD28 costimulatory receptor (18-20). Cross-linking of the TCR/CD3 complex in the absence of a CD28-mediated costimulatory signal induces a proliferative unresponsiveness that is mediated by the inability of T cells to produce IL-2 (21). CD28 costimulation prevents proliferative unresponsiveness in Th1 cells by augmenting the production of IL-2, which in turn promotes IL-4 secretion by T cells (22). The costimulatory pathway of $\mathrm{T}$ cell activation involves interaction of $\mathrm{CD} 28$ with its ligands B7-1 and B7-2 on an antigen-presenting cell (APC), with B7-2 considered as the primary ligand for CD28 (23-26). When costimulation is blocked by either CTLA4-Ig or by antiB7-1 or anti B7-2 mAbs, differential effects on the incidence of various autoimmune diseases (e.g., IDDM) and on the development of Th1 and Th2 cells are observed $(27,28)$. Furthermore, in vivo studies have demonstrated that generation of $\mathrm{Th} 2$ cells is more dependent upon the CD28-B7 pathway than is the 
priming of Th1 cells, and suggest that the development of Th subsets in vivo may be influenced by limiting CD28-B7 costimulation $(29,30)$. These conclusions were recently confirmed using the CTLA-4Ig transgenic and CD28-deficient mouse models (31-33). Analyses of human Th2 cell development have yielded results similar to those observed in the mouse (34-36). Interestingly, interactions between CD28 and its B7-2 ligand are essential for costimulation of an IL-4-dependent $\mathrm{CD}^{+}{ }^{+} \mathrm{T}$ cell response, and IL-4 increases B7-1 and B7-2 surface expression on certain professional APCs (e.g., Langerhans cells) and B cells $(26,37,38)$. Thus, NOD APCs may optimally activate islet $\beta$ cell autoreactive $\mathrm{CD}^{+}$effector $\mathrm{T}$ cells, but not regulatory $\mathrm{CD}^{+}{ }^{+} \mathrm{T}$ cells $(39,40)$. Deficient $\mathrm{CD} 28$ costimulation may lower the ability of NOD APCs to stimulate regulatory $\mathrm{Th} 2$ cells without compromising their ability to stimulate autoreactive effector Th1 cells.

In this study, we show that anti-CD28 mAb-mediated costimulation completely restores the proliferative responsiveness of NOD thymocytes and peripheral T cells by augmenting their levels of secretion of IL-2 and IL-4. This result raised the possibility that treating NOD mice with a CD28 agonist, which can stimulate marked IL-4 secretion and is more stable than IL-4 in vivo, may be more efficacious than IL-4 in protecting NOD mice from IDDM. NOD mice were therefore treated with an anti-CD28 mAb to determine whether CD28 costimulation protects them from IDDM. We demonstrate that anti-CD28 treatment effectively prevents destructive insulitis and protects from IDDM in NOD mice, provided that treatment is performed at a sufficiently early age (2-4 wk) during neonatal life. Our data support the hypothesis that NOD APCs may not provide a sufficient CD28 costimulation signal during the inductive phase of development of IDDM, and that this CD28 signal is requisite for activation of IL-4-producing NOD Th2 cells and protection from IDDM.

\section{Methods}

Mice. Our NOD/Del mouse colony was bred and maintained in a specific pathogen-free facility at The John P. Robarts Research Institute (London, ON). Diabetes incidence among females in our NOD colony is presently $40-50 \%$ at 15 wk of age and $80-90 \%$ by 25 wk. NOD.Scid mice generously provided by Dr. L. Shultz (The Jackson Laboratory, Bar Harbor, ME) were bred in our colony and used as recipients in $\mathrm{T}$ cell transfer experiments. The age- and sex-matched $\mathrm{BALB} / \mathrm{c}$ mice used as controls in the in vitro $\mathrm{T}$ cell proliferation experiments were also bred in our colony.

Anti-CD28 mAb treatment. In the first experiment, either anti$\mathrm{CD} 28 \mathrm{mAb}(50 \mu \mathrm{g})$, purified by protein $\mathrm{G}$ affinity chromatography (Pharmacia Biotech, Uppsala, Sweden) of supernatants from 37.51 hybridoma cells secreting hamster antimurine CD28 mAbs (41) (kindly provided by Dr. J. Allison, University of California, Berkeley, CA), or control hamster IgG (50 $\mu \mathrm{g}$, Bio/Can Scientific, Mississauga, $\mathrm{ON})$ was administered intraperitoneally every other day to female NOD mice ( $n=20 /$ group, randomized from 10 different litters) from 2 to $4 \mathrm{wk}$ of age. These mice were then boosted at 6,7 , and 8 wk of age. In a second experiment, female NOD mice $(n=10-12 /$ group randomized from 3 to 4 different litters) received anti-CD28 mAb (50 $\mu \mathrm{g})$ plus either anti-IL-4 mAb (42) $(50 \mu \mathrm{g}, 11 \mathrm{~B} 11)$ or control rat IgG $(50 \mu \mathrm{g}$; Bio/Can Scientific, Mississauga, ON), or anti-IL-4 mAb (50 $\mu \mathrm{g}, 11 \mathrm{~B} 11)$ alone, according to the same schedule used in the first experiment. In a third experiment NOD mice ( $n=10$ /group, randomized from five different litters) received the same treatment starting at $5 \mathrm{wk}$ of age. Blood glucose levels (BGL) were measured weekly with a Glucometer Encore (Miles/Bayer, Toronto, ON). Animals with
BGL > $11.1 \mathrm{mmol} / \mathrm{liter}(200 \mathrm{mg} / \mathrm{dl})$ during two consecutive wk were considered diabetic.

Histopathology analysis. Mice were harvested periodically during the course of anti-CD28 or control treatment, and pancreatic tissue was removed, fixed with $10 \%$ buffered formalin, embedded in paraffin, and sectioned at 5- $\mu \mathrm{m}$ intervals. The incidence and severity of insulitis was examined by hematoxylin and eosin staining as well as insulin immunostaining. A minimum of 20 islets from each mouse were observed, and the degree of mononuclear cell infiltration was scored by two independent blinded observers using the following ranking: 0 , normal; 1, periinsulitis (mononuclear cells surrounding islets and ducts, but no infiltration of the islet architecture); 2 , moderate insulitis (mononuclear cells infiltrating $<50 \%$ of the islet architecture); and 3 , severe insulitis ( $>50 \%$ of the islet tissue infiltrated by lymphocytes and/or loss of islet architecture). Immunohistochemical detection of insulin was performed using a porcine anti-insulin antibody and avidin-biotin peroxidase technique (Dako Corp., Carpinteria, CA).

Cell proliferation and cytokine secretion. Splenocytes and thymocytes were isolated as described (13). Splenic T cells were isolated on T cell columns (R\&D Systems, Minneapolis, MN) to a purity of $\geq 98 \%$, as assayed by FACS analysis of CD3 cell surface expression. Cells $\left(10^{6} / \mathrm{ml}\right)$ were cultured in RPMI 1640 medium supplemented with $10 \%$ heat-inactivated FCS, $10 \mathrm{mM}$ Hepes buffer, $1 \mathrm{mM}$ sodium pyruvate, $2 \mathrm{mM} \mathrm{L}$-glutamine, $100 \mathrm{U} / \mathrm{ml}$ penicillin, $0.1 \mathrm{mg} / \mathrm{ml}$ streptomycin, and $0.05 \mathrm{mM}$ 2-ME (all purchased from Gibco Laboratories, Grand Island, NY) with plate-bound 145-2C11 anti-CD3€ mAb (1/500 dilution of ascites; hybridoma kindly supplied by Dr. J. Bluestone, University of Chicago, Chicago, IL) in the presence or absence of various concentrations of the 37.51 anti-CD28 mAb. Cells were harvested after either 48 (splenocytes and T cells) or $72 \mathrm{~h}$ (thymocytes), and were then assayed for incorporation of $\left[{ }^{3} \mathrm{H}\right]$ thymidine $(1 \mu \mathrm{Ci} /$ well; Amersham, Oakville, $\mathrm{ON}$ ) added during the last $18 \mathrm{~h}$ of culture. Islet-infiltrating cells were purified after isolation of pancreatic islets by collagenase P (Boehringer Mannheim, Laval, QC) digestion and centrifugation of the islets on a discontinuous Ficoll gradient. Free islets were hand-picked under a dissecting microscope to a purity of $\geq 95 \%$, and purified islets were cultured for $24 \mathrm{~h}$ to allow emigration of lymphocytes from the islets. After culture harvest and isolation of viable lymphocytes by density gradient centrifugation on Lympholyte-M (Cedarlane Laboratories, Ltd., Hornby, ON), the cells were cultured for $48 \mathrm{~h}$ with anti-CD3 as above.

Culture supernatants were assayed for their concentration of cytokines by ELISA. IL-4 levels were interpolated from a standard curve using recombinant mouse IL-4 captured by the BVD4-1D11 $\mathrm{mAb}$ and detected by the biotinylated BVD6-24G2 mAb, while IFN- $\gamma$ concentrations were measured using rmIFN- $\gamma$, the R4-6A2 mAb, and biotinylated XMG1.2 mAb (all obtained from PharMingen, Mississauga, ON). Standard curves were linear in the range of $20-2,000 \mathrm{pg} /$ $\mathrm{ml}$. In some experiments, the relative levels of IL-2 and IL-4 secreted were quantified in a bioassay using the IL-2 dependent CTLL-2 T cell line (43) and IL-4 dependent CT.4S T cell line (44) (supplied by Dr. W.E. Paul, Laboratory of Immunology, National Institute of Allergy and Infectious Diseases, Bethesda, MD). Twofold serial dilutions of test supernatants were added to CTLL-2 cells $\left(1.5 \times 10^{4}\right)$ and CT.4S cells $\left(5 \times 10^{3}\right)$, which were cultured for 24 and $48 \mathrm{~h}$, respectively, in flat-bottomed 96-well plates. Cell proliferation was assessed by addition of $\left[{ }^{3} \mathrm{H}\right]$ thymidine for $8 \mathrm{~h}$ before termination of culture, and $\left[{ }^{3} \mathrm{H}\right]$ thymidine incorporation was determined as above. To assess the ability of either anti-IL-2 (S4B6) (45) or anti-IL-4 (11B11) mAbs to inhibit CD28 costimulation of anti-CD3 activated T cells, the percentage inhibition of CD28 costimulation was calculated as follows:

Percentage of inhibition $=$

$1-\frac{([\mathrm{S}-\mathrm{U}] \text { in the presence of an inhibitor } \mathrm{mAb})}{([\mathrm{S}-\mathrm{U}] \text { in the absence of an inhibitor } \mathrm{mAb})} \times 100$

where $\mathrm{S}$ is the amount of $\mathrm{CD} 28$ costimulation-induced proliferation (or cytokine production) of anti-CD3 plus anti-CD28-stimulated 
cells, and $\mathrm{U}$ is the amount of proliferation (or cytokine production) of cells activated by anti-CD3 alone.

Intrapancreatic cytokine analysis. Intrapancreatic IL-4 and IFN- $\gamma$ concentrations in tissue samples were quantified as described (46). In brief, pancreata were isolated and snap frozen in liquid nitrogen. Upon analysis, the samples were homogenized and sonicated in protease inhibitor-buffered cocktail followed by filtration through $1.2-\mu \mathrm{m}$ filters (Gelman Sciences, Inc., Ann Arbor, MI). The filtrates were analyzed for IL- 4 and IFN- $\gamma$ concentrations by ELISA, and the ELISA results were normalized relative to the total amount of protein per pancreas and recorded as $\mathrm{ng} / \mathrm{mg}$ tissue.

Glutamic acid decarboxylase (GAD) antibody ELISA. The presence of anti-GAD antibodies in collected sera was determined by ELISA as previously described (47). In brief, sera samples were added at appropriate dilutions to plates coated with murine $\mathrm{GAD}_{67}$ $(10 \mu \mathrm{g} / \mathrm{ml})$. Using alkaline phosphatase-conjugated goat anti-mouse isotype (IgG1 or IgG2a) antibodies with $p$-nitrophenylphosphate disodium in diethylamine buffer (substrate) the optical density was read at $405 \mathrm{~nm}$ to determine the relative amount of the individual antiGAD isotype. All sera were titrated at 1:20, 1:40, 1:80, and 1:160 dilutions for anti-GAD ${ }_{67}$ antibodies. Since we found significant differences between the IgG1 and $\operatorname{IgG} 2$ a ratio at the 1:20 dilution between treated and untreated mice, all sera were tested for the specific isotypes (IgG1 and $\mathrm{IgG} 2 \mathrm{a})$ at the 1:20 dilutions.

Adoptive cell transfer. Female NOD.Scid mice $(n=5$ /group) 6-8 wk of age were each injected intraperitoneally with splenic T cells $\left(10^{7}\right)$ from prediabetic female NOD mice previously treated with anti-CD28 mAb or control Ig. The recipients were followed for a maximum of $12 \mathrm{wk}$ after transfer, and BGL were monitored weekly.

Flow cytometry analysis. Splenic T cells and thymocytes $\left(10^{5}\right)$ were suspended in $0.1 \%$ BSA and PBS $/ 0.001 \% \mathrm{NaN} 3$, and were then incubated for $30 \mathrm{~min}$ at $4{ }^{\circ} \mathrm{C}$ with various FITC- or PE-conjugated $\mathrm{mAbs}$ against different murine lymphocyte subpopulations and functional markers, including CD3, CD4, CD8, CD19, CD25, CD69, CD44, L-selectin, CD40, LFA-1, B7-1, and B7-2 (PharMingen). Isotype-matched (Ig) antibodies were used as negative controls. Cell fluorescence was analyzed using a FACScan and Lysis II software (both from Becton-Dickinson, San Jose, CA).

\section{Results and Discussion}

CD28 costimulation restores NOD $T$ cell proliferative responsiveness. A primary role of CD28 costimulation is the augmentation of IL-2 production by activated T cells. If exogenous IL-2 is present at a high concentration, specific intracellular signals derived from CD28-mediated costimulation are unnecessary for maximum Th1 proliferation and optimal Th2 responsiveness to IL-4 (22). Addition of IL-2 can also overcome the inability of Th1 cells to proliferate (21). Nonetheless, we previously showed that exogenous IL-2, even when added at high concentrations, only partially restores TCR-induced NOD thymocyte and peripheral $\mathrm{T}$ cell proliferative responsiveness due to its inability to restore a normal level of IL-4 production (13). In contrast, exogenous IL-4 completely restores the TCR-mediated responsiveness of NOD T cells, and this is associated with increased IL-2 production by these $T$ cells. These data raise the possibility that the costimulatory signal transduced by CD28 on NOD T cells may be insufficient to stimulate optimum NOD T cell activation.

To test this possibility, we assayed the ability of an anti$\mathrm{CD} 28 \mathrm{mAb}$ to augment the costimulation signal provided by NOD APCs to NOD T cells, and stimulate the TCR-mediated in vitro proliferation of NOD and BALB/c thymocytes. 8-wk-old mice were used, since the trait of $\mathrm{T}$ cell proliferative hyporesponsiveness is readily detectable in NOD mice at this age
(12). Fig. $1 A$ shows that CD28 costimulation provided by antiCD28 markedly enhances the anti-CD3-induced proliferative responses of NOD and BALB/c thymocytes, yielding 19.5- and 5.6-fold increases (at the highest concentration of anti-CD28) in these responses, respectively. Note also that the response to anti-CD3 mAb alone is significantly higher in control BALB/c than NOD thymocytes (Fig. 1, $A$ and $E$ ), confirming the NOD $\mathrm{T}$ cell proliferative hyporesponsiveness reported in our previous work $(12,13)$. When quiescent NOD and BALB/c thymocytes were stimulated by anti-CD28 in the absence of antiCD3 (or anti-TCR $\alpha \beta$ ), however, a low level of proliferation was observed which was equivalent to the basal proliferative response detected in the absence of any stimulus (data not shown). The negligible effect of anti-CD28 stimulation on $\mathrm{T}$ cell activation in the absence of TCR ligation agrees with the result predicted by a recently proposed model of T cell-APC interaction (18). Anti-CD28 mAb also significantly enhanced the NOD, and to a lesser extent the BALB/c, anti-CD3-induced splenic $\mathrm{T}$ cell proliferative response (Fig. $1 B$ ). Thus, CD28 costimulation is able to restore NOD thymocyte and T cell proliferation to levels similar to the levels found in $\mathrm{BALB} / \mathrm{c}$ and other control strains (Fig. 1, $A, B$, and $E$ ).

CD28 costimulation activates $I L-2$ and $I L-4$ production by NOD T cells. CD28 costimulation of IL-2 production enhances IL- 4 production by T cells (22), and CD28 costimulation also induces the responsiveness of Th2 cells to IL-4 (48). We reasoned, therefore, that $\mathrm{CD} 28$ costimulation may restore NOD $T$ cell responsiveness by augmenting production of not only IL-2, but also IL-4. Fig. $1 C$ demonstrates that anti-CD3 plus anti-CD28 costimulation significantly increases IL-2 production by both NOD (21.6-fold) and BALB/c (8.1-fold) thymocytes. In contrast, anti-CD28 significantly enhanced antiCD3-stimulated IL-4 production by NOD (5.5-fold increase) but not BALB/c thymocytes (Fig. $1, D$ and $G$ ). This result may be due to higher anti-CD3 induced IL-4 production by BALB/c T cells without the requirement of costimulation. NOD mice may be deficient in generating differentiated Th2 cells, and therefore require CD28 costimulation for IL-4 production (49). A higher anti-CD3 stimulated production of IL-4 has also been found in other diabetes-resistant strains (our unpublished results [50]). The failure of TCR-stimulated CD4 $4^{+}$NOD thymocytes to produce IL-4 (13) likely facilitates detection of a significant increase in IL-4 production upon costimulation by anti-CD28. Note that CD28 costimulation augments the proliferative responsiveness as well as IL-2 and IL-4 production by NOD thymocytes to levels comparable to those of BALB/c thymocytes. This augmentation may occur by a CD28-mediated pathway that significantly enhances the differentiation and ability of NOD thymocytes to produce IL-4, which can subsequently stimulate $\mathrm{T}$ cell proliferation in an autocrine and/ or paracrine fashion $(51,52)$. Our finding that IL-4 restores the proliferative responsiveness of NOD thymocytes by increasing their level of IL-2 production (13) agrees closely with the reported role for IL-4 in the stimulation of IL- 2 production by mouse $\mathrm{T}$ cells in response to plate-bound anti-CD3 (53).

To examine whether CD28 costimulation of NOD thymocytes is dependent upon upregulation of IL-4 and/or IL-2 production, we assayed the capacity of anti-CD28 to costimulate anti-CD3-induced NOD and BALB/c T cell proliferative responses in the presence of anti-IL-4, anti-IL-2, or both of these mAbs. Anti-IL-4 inhibited $\sim 33 \%$ of the CD28 costimulatory response of NOD thymocytes, but did not inhibit CD28 

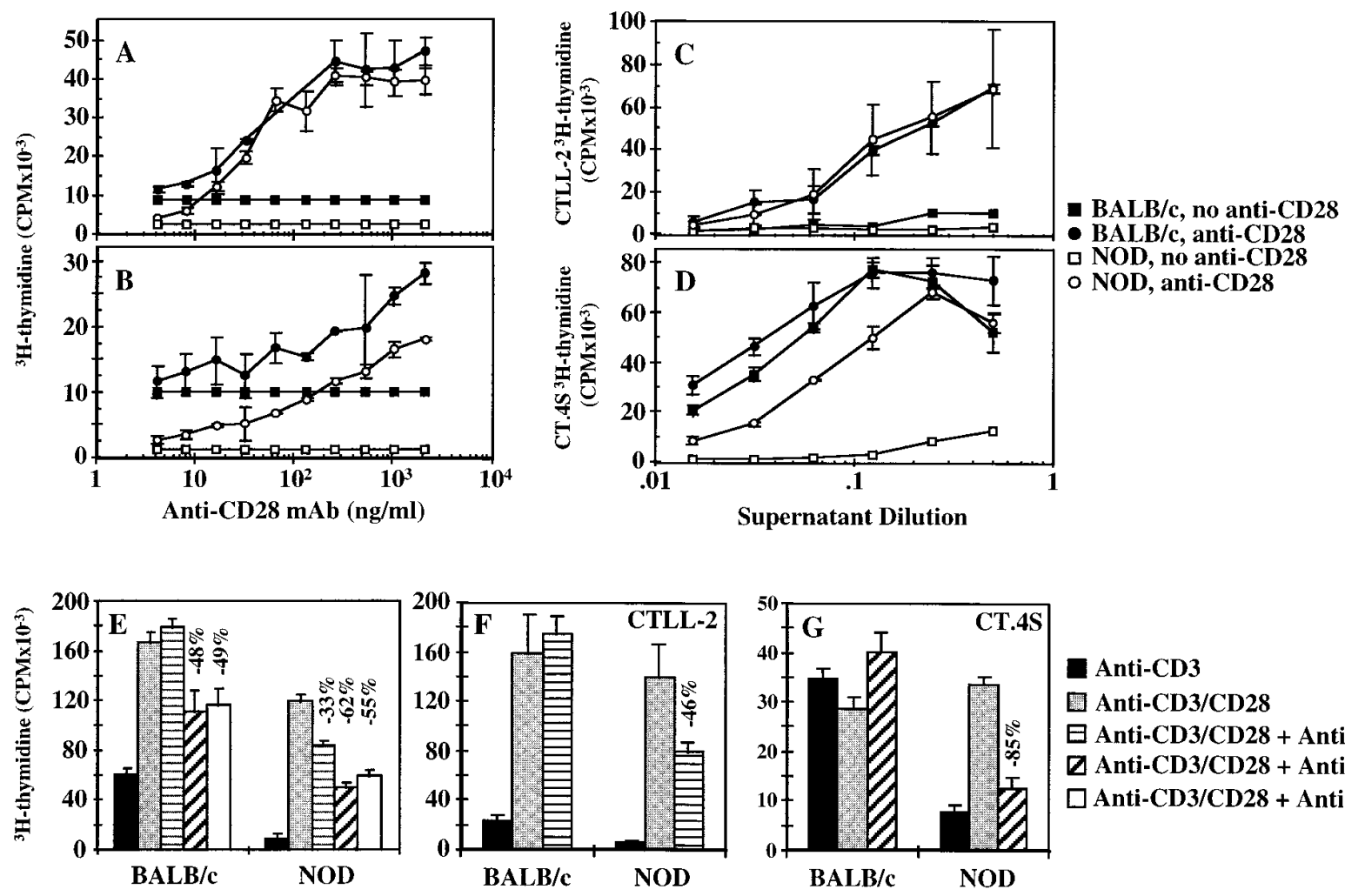

Anti-CD3

圆 Anti-CD3/CD28

日 Anti-CD3/CD28 + Anti-IL-4

$\square$ Anti-CD3/CD28 + Anti-IL-2

$\square$ Anti-CD3/CD28 + Anti-IL-2/IL-4

Figure 1. CD28 costimulation restores the proliferative responsiveness of activated NOD thymic and splenic T cells, and augments IL-2 and IL-4 production by activated NOD thymocytes. Thymocytes $(A)$ and splenic T cells $(B)$ from 8-wk-old NOD and control BALB/c mice were activated by plate-bound anti-CD3 in the absence (squares) or presence (circles) of varying dilutions ( $2 \mathrm{ng} / \mathrm{ml}-2 \mu \mathrm{g} / \mathrm{ml})$ of soluble anti-CD28 mAb. Cell proliferation was determined by $\left[{ }^{3} \mathrm{H}\right]$ thymidine incorporation. The results of triplicate cultures are expressed as the mean values \pm SD, and are representative of three different experiments. In $C$ and $D, \mathrm{NOD}$ and BALB/c thymocytes from 8-wk-old mice were activated by plate-bound anti-CD3 in the absence (squares) or presence (circles) of $1 \mu \mathrm{g} / \mathrm{ml}$ soluble anti-CD28 mAb (optimal concentration). Culture supernatants were removed, diluted and assayed for their IL-2 $(C)$ and IL-4 $(D)$ content by stimulation of proliferation of the CTLL-2 and CT.4S T cell lines, respectively. The CTLL-2 cpm values of [ $\left.{ }^{3} \mathrm{H}\right]$ thymidine incorporation for anti-CD3 activated NOD and BALB/c T cells represented by the highest supernatant dilution were 9,064 $\pm 1,246$ and 3,715 \pm 940 , respectively. In $E$, BALB/c and NOD mice thymocytes were activated by plate-bound anti-CD3 in the absence or presence of soluble anti-CD28 (1/400 dilution of hybridoma ascites). Parallel cultures activated by anti-CD3 plus anti-CD28 were supplemented with anti-IL-2 $(40 \mu \mathrm{g} / \mathrm{ml})$, anti-IL-4 $(40 \mu \mathrm{g} / \mathrm{ml})$, or both mAbs. Supernatants from similar cultures were assayed for their IL-2 $(F)$ and IL-4 $(G)$ activities, as above. Percent inhibition of CD28 costimulation of thymocyte proliferation achieved by anti-IL-2 or anti-IL-4 are indicated above the corresponding bars. In $C-G$, the results of triplicate cultures are expressed as the mean values \pm SD, and are representative of four different experiments.

costimulation of BALB/c thymocytes (Fig. $1 E$ ). CD28 costimulation of proliferation is therefore partially dependent on IL-4 production by NOD thymocytes, but not by control BALB/c thymocytes. We also found that anti-IL-4 partially blocked (46\% inhibition) CD28 costimulation of IL-2 production by NOD thymocytes, but did not affect CD28 costimulation of IL-2 production by BALB/c thymocytes (Fig. $1 F$ ). In contrast, anti-IL-2 inhibited almost completely ( $85 \%$ inhibition) the amount of CD28 costimulation of IL-4 production by NOD thymocytes, but did not block CD28 costimulation of IL-4 production by BALB/c thymocytes (Fig. $1 G$ ). Thus, restoration of NOD thymocyte responsiveness by CD28 costimulation is dependent partially on enhanced IL-4 and IL-2 production.

Defective $T$ cell activation in NOD mice $(12,39,54)$ may account for the functional inactivation of regulatory peripheral Th2-like cells and lack of tolerance to pancreatic $\beta$ cell antigens in NOD mice $(3,55,56)$. Exogenous IL-4 prevents the onset of IDDM in NOD mice; this prevention is associated with the restoration of $\mathrm{T}$ cell proliferative responsiveness and aug- mentation of IL-2 production in vitro (13). Our data presented here suggest that NOD T cell proliferative responsiveness can be restored by CD28-mediated costimulation via a mechanism that is partially, if not primarily, dependent on the enhancement of IL-2 and IL-4 production, respectively.

$C D 28$ costimulation prevents destructive insulitis and IDDM in NOD mice. Our result that IL-4 treatment of NOD mice prevents insulitis and IDDM (13), and finding in this report that CD28 costimulation markedly enhances IL-4 production by NOD T cells, prompted us to investigate whether CD28mediated costimulation prevents insulitis and IDDM in NOD mice. We found that anti-CD28 treatment of NOD mice during the inductive phase (2-4 wk of age) of IDDM development prevents destructive insulitis (Fig. 2) and completely protects against IDDM (Fig. $3 A$ ). Note that in 25-wk-old anti-CD28 treated NOD mice (Fig. $2 B$ ), the percentage (19\%) of islets displaying severe insulitis (insulitis score $=3$ ) was considerably lower than that observed $(46 \%)$ in control-treated mice. Anti-CD28 treated animals still possessed $22 \%$ normal healthy 

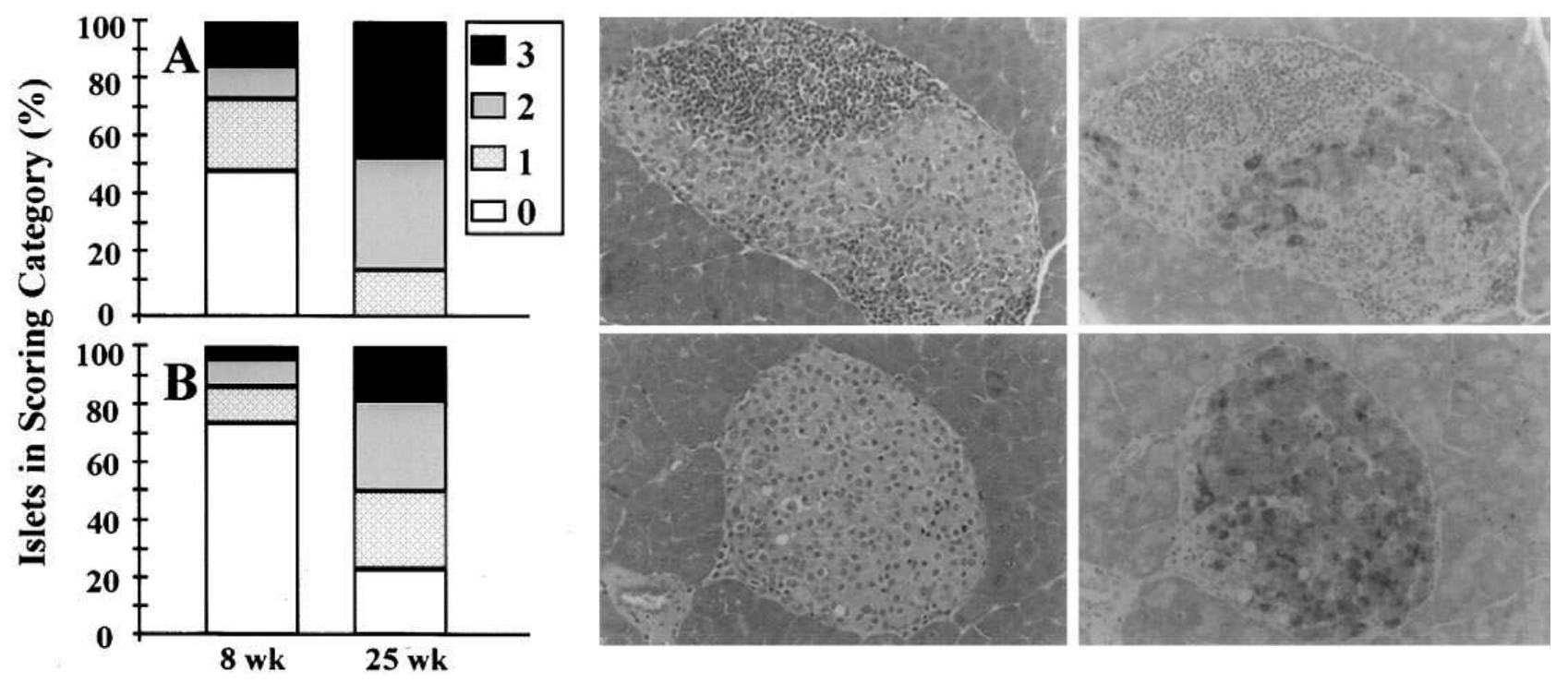

Figure 2. Anti-CD28 treatment prevents destructive insulitis in female NOD mice. After hematoxylin and eosin staining, a minimum of 20 islets from each NOD mouse were observed, and the degree of mononuclear cell infiltration was scored independently by two observers as follows: 0 , normal; 1, periinsulitis (mononuclear cells surrounding islets and ducts but not infiltrating the architecture); 2, moderate insulitis (mononuclear cells infiltrating $<50 \%$ of the islet architecture); and 3, severe insulitis ( $>50 \%$ of the islet tissue infiltrated by lymphocytes and/or loss of islet architecture). (A) 8- and 25-wk-old NOD mice $(n \geq 5)$ injected with control hamster IgG. (B) 8-and 25-wk-old NOD mice $(n \geq 5)$ injected with anti-CD28 mAb. Representative islets stained with hematoxylin and eosin (photo left) or insulin (photo right) are also presented. Note the destructive insulitis accompanied by a reduction in the number of insulin-producing cells in a representative islet from control IgG-treated mice at $8 \mathrm{wk}$ of age $(A$, photo left and right). Note also the nondestructive periinsulitis in a representative islet from anti-CD28-treated mice at 8 wk of age ( $B$, photo left and right).

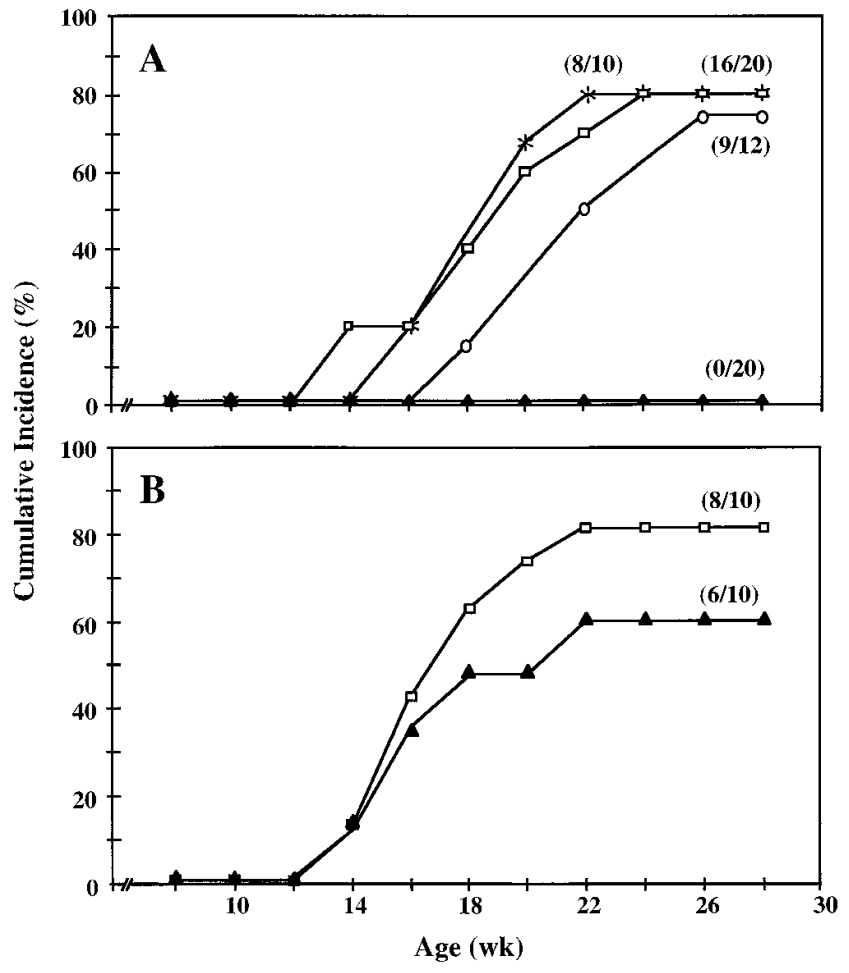

Figure 3. Anti-CD28 mAb treatment prevents IDDM in female NOD mice, and this protection is abrogated by anti-IL-4 mAb treatment. $(A) 20$ female NOD prediabetic mice (randomized from five different litters) were injected three times weekly from two to four wk of age with $50 \mu \mathrm{g}$ of either the 37.51 anti-CD28 mAb or con- islets (insulitis score $=0$ ), while normal islets were not present in the control animals. In contrast, when anti-CD28 mAb was administered together with anti-IL-4 mAb, the protective effect of anti-CD28 mAb was abrogated $(75 \%$ of treated mice became diabetic at $25 \mathrm{wk}$ ) (Fig. $3 A$ ). This result suggests that anti-CD28 $\mathrm{mAb}$ is an effective stimulator of IL-4 production by NOD T cells, and that the IL- 4 secreted as a consequence of this stimulation is neutralized by anti-IL-4. Also note that NOD mice that received anti-IL-4 mAb alone displayed a similar incidence of IDDM as control IgG-treated mice. This observation is consistent with a report of the effect of treating NOD mice with various anticytokine mAbs, in which antiIFN- $\gamma$ was found to protect against IDDM while neither antiIL-4, anti-IL-5, nor anti-IL-10 administration had any significant effect (57). Collectively, these results indicate that IL-4

trol hamster $\operatorname{IgG}$, and then boosted at six, seven, and eight wk of age. In addition, 10-12 mice (randomized from three to four different litters) were treated with anti-CD28 plus either the 11B11 anti-IL-4 $\mathrm{mAb}$ or control rat IgG, or 11B11 anti-IL-4 mAb alone. Control rat IgG treatment results are not shown, as they were similar to those obtained with control hamster IgG treatment. $(B)$ Another group of ten females (randomized from three different litters) were similarly treated from five to seven wk of age. Mice were screened weekly for the presence of hyperglycemia (BGL $>11.1 \mathrm{mmol} /$ liter) starting at 8 wk of age. Diabetes was diagnosed when mice were hyperglycemic for two consecutive readings. Open squares, control; closed triangles, anti-CD28; asterisks, anti-IL-4; open circles, anti-CD28 + anti-IL-4. 
plays an important role as a mediator of the anti-CD28 mediated protective effect.

Interestingly, when anti-CD28 treament was initiated after the onset of insulitis at $5 \mathrm{wk}$ of age, significantly less protection from insulitis (data not shown) and IDDM (Fig. $3 \mathrm{~B}$ ) was observed. This result emphasizes the age dependency of successful immune intervention in NOD mice $(3,28,33)$. It also indicates that CD28 mAb administration may represent a form of immunostimulation of NOD T cells that effectively protects against IDDM, particularly when anti-CD28 treatment is administered during the inductive phase of the disease. Indeed, the same mAb purified from supernatants of the $37.51 \mathrm{~B}$ cell hybridoma was recently demonstrated to function by activation of CD28 signaling in vivo $(58,59)$.

Our observations in Figs. 2 and 3 are consistent with the recent report that disruption of the $\mathrm{CD} 28 / \mathrm{B} 7$ pathway early in either CD28-deficient or CTLA4Ig transgenic NOD mice promotes the development and progression of IDDM (33). Together, these two sets of findings indicate that activation of NOD T cells by the CD28/B7 pathway is required to protect NOD mice from destructive insulitis and the onset of IDDM. Our data suggest that the anti-CD28 mAb used to treat NOD mice may prevent IDDM by activating the CD28 signaling pathway in NOD $\mathrm{T}$ cells rather than by blocking the interaction between CD28 and B7. Alternatively, we cannot formally rule out the possibility that anti-CD28 blocks CD28-B7-2 interaction, enabling a higher avidity interaction between CTLA4 and B7-1 to occur. The latter interaction may downregulate T-APC interaction and prevent IDDM in NOD mice (60). The age-dependent cytokine profiles (shown below) observed in thymocytes and peripheral $\mathrm{T}$ cells throughout the period of
anti-CD28 treatment of NOD mice, viz. the high levels of IL-4 secretion compared with the decreasing levels of IFN- $\gamma$, however, also support the idea that anti-CD28-induced protection from IDDM is mediated by a polarized increase in Th2-like activity rather than a decrease in Th1-like activity.

Anti-CD28 treatment elicits the expansion and survival of Th2 cells. Prevention of IDDM by CD28 costimulation may be mediated by the activation of a subset of $\mathrm{CD} 4^{+}$regulatory $\mathrm{T}$ cells that confer protection against IDDM. This subset of $\mathrm{CD} 4^{+}$ regulatory $\mathrm{T}$ cells may be hyporesponsive in NOD mice, and may not receive a sufficient amount of the CD28/B7 costimulatory signal required for clonal expansion and effector function in NOD mice (61). It has been proposed that precursor $\mathrm{CD} 4^{+} \mathrm{Th} 2$ cells require a strong initial $\mathrm{T}$ cell stimulation, and that the amount of IL-4 produced is proportional to the magnitude of the initial $\mathrm{T}$ cell stimulation. In the absence of CD28 costimulation, IL-4 production remains below the threshold required for optimal development of Th2 cells $(19,20,62)$. It is of interest that B7-1 and B7-2 ligation of CD28 mediate distinct outcomes in $\mathrm{CD}^{+} \mathrm{T}$ cells. B7-2 costimulation signals naive $\mathrm{T}$ cells to become IL-4-producing $\mathrm{T}$ cells, and thereby directs an immune response towards $\mathrm{Th} 0$ and $\mathrm{Th} 2$ cells $(26,27$, 63). B7-1 costimulation seems to be a more neutral differentiative signal, and initiates development of both Th1 and Th0/Th2 cells. Presumably, B7-2 plays a dominant role in production of IL-4 because of its early expression during $\mathrm{T}$ cell activation $(20,26)$. Thus, an insufficient or inappropriate signal resulting from a CD28/B7-2 interaction may be delivered to a subset of regulatory $\mathrm{CD}^{+} \mathrm{T}$ cells in NOD mice, and this subset may not differentiate properly into functional IL-4 producing Th2 cells.

We tested this hypothesis by analyzing whether anti-CD28

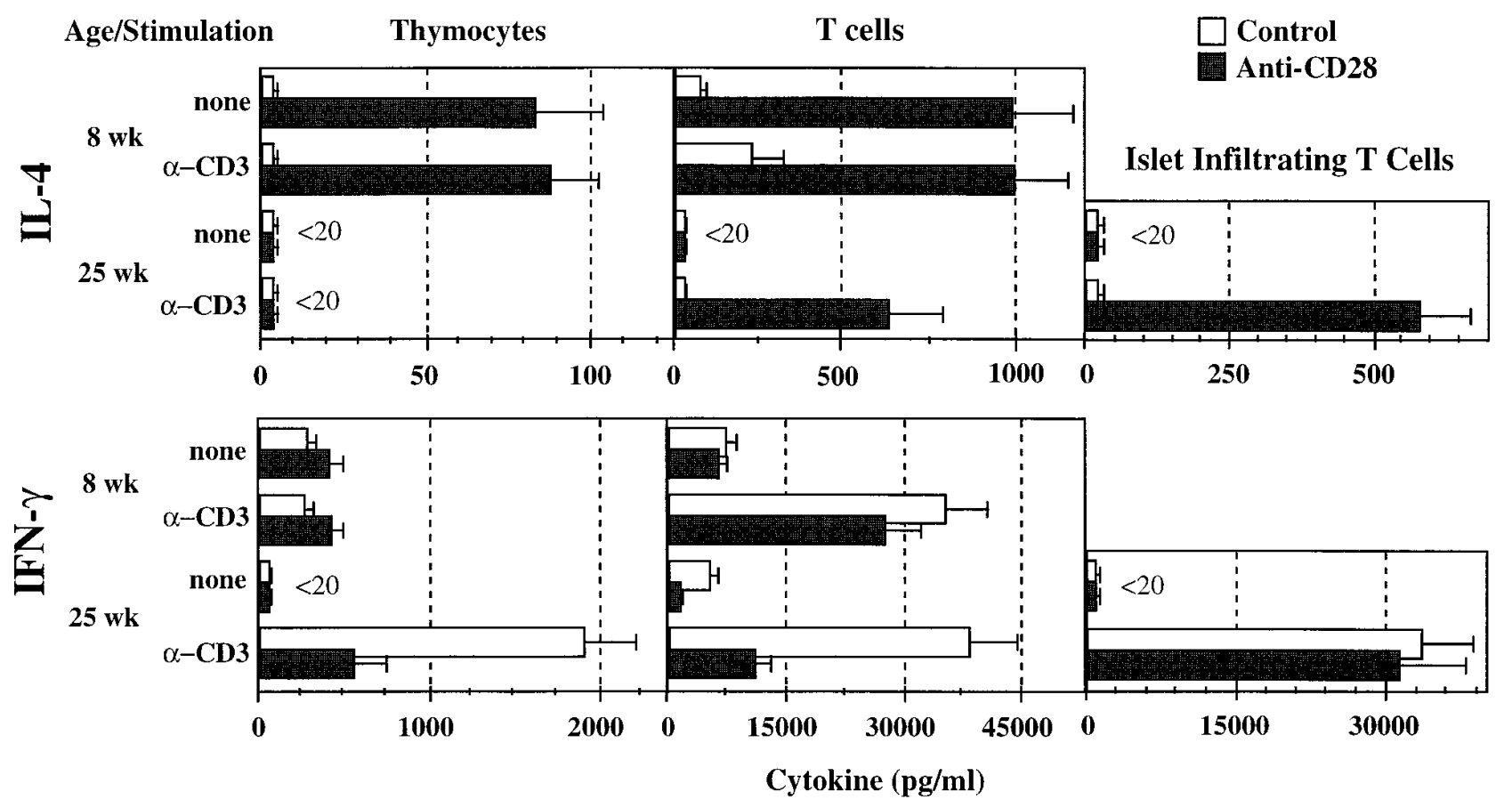

Figure 4. Anti-CD28 mAb treatment induces IL-4 production in NOD mice. Thymocytes, splenic T cells, and islet infiltrating cells (106/ml) were pooled from at least three age-matched NOD mice at various times after treatment with anti-CD28 mAb or control Ig, and were then stimulated with the 145-2C11 anti-CD3€ mAb (plate-bound, 1/500 ascites dilution). After either 72 (thymocytes) or $48 \mathrm{~h}$ ( $\mathrm{T}$ cells and islet infiltrating cells) of culture, the concentrations of IFN- $\gamma$ and IL-4 in cell supernatants from triplicate cultures were determined by ELISA. Values shown are the mean \pm SEM of three separate experiments. 

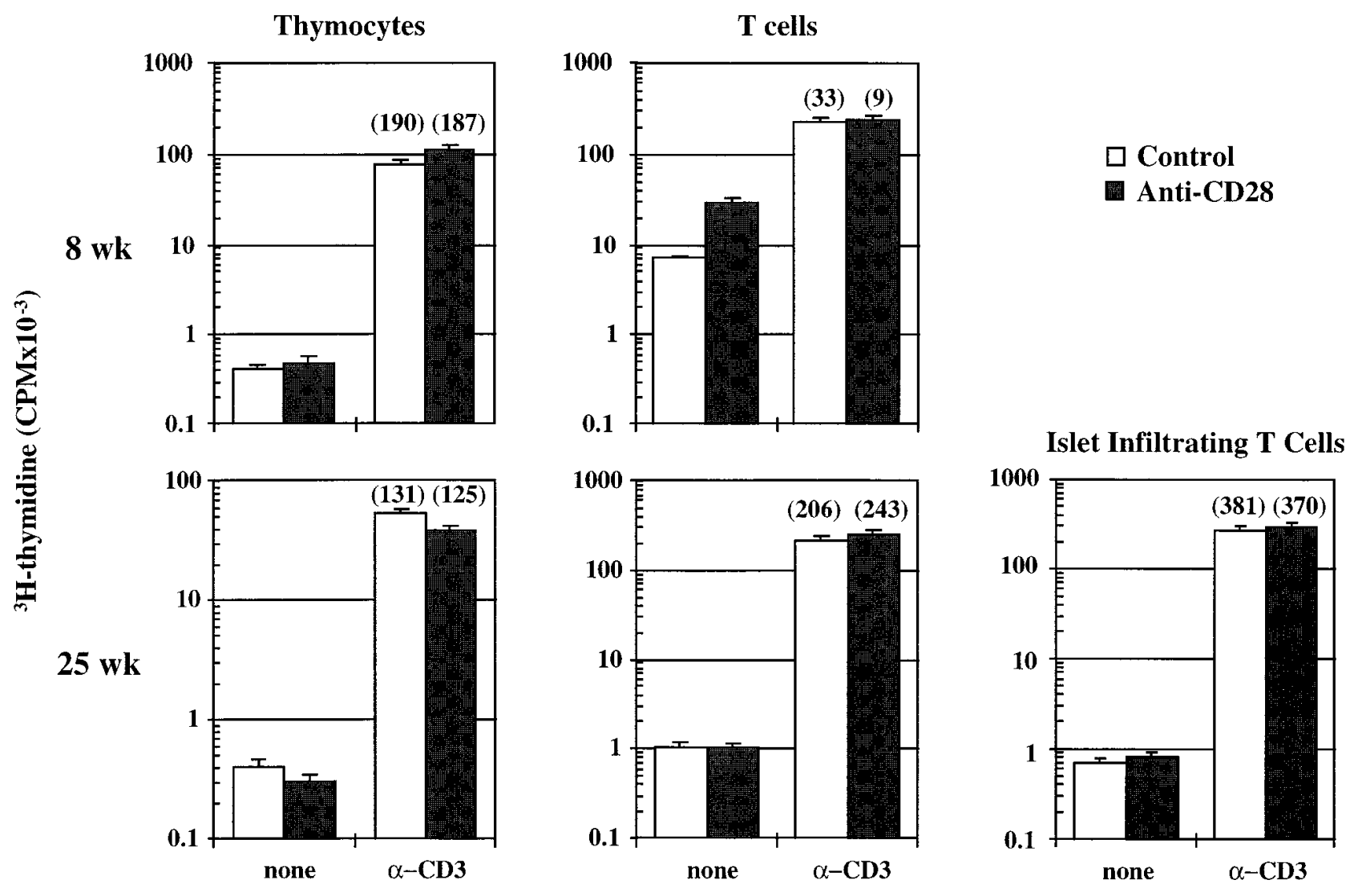

\section{Stimulation}

Figure 5. Anti-CD28 mAb administration in vivo enhances basal splenic $\mathrm{T}$ cell proliferative responses but not $\mathrm{T}$ cell proliferation in response to anti-CD3. Thymocytes, T cells and islet infiltrating cells $\left(2 \times 10^{5} /\right.$ well $)$ from 8 - and 25-wk-old NOD mice $(n \geq 3)$ injected with either anti-CD28 $\mathrm{mAb}$ or control hamster Ig were cultured in triplicate wells in the presence of the plate-bound 145-2C11 anti-CD3€ mAb (1/500 ascites) for 48 ( $\mathrm{T}$ cells, infiltrating cells) or $72 \mathrm{~h}$ (thymocytes). Cell proliferation was determined by $\left[{ }^{3} \mathrm{H}\right]$ thymidine incorporation. Values (mean cpm $\pm \mathrm{SD}$ ) shown are representative of three separate experiments. Stimulation indices were calculated as the ratio of average cpm of anti-CD3 stimulated cultures/average cpm of control cultures, and are shown in parentheses.

$\mathrm{mAb}$ treatment of NOD mice provides the costimulation required for the expansion of and cytokine production by regulatory IL-4-producing Th2-like cells. Fig. 4 shows that antiCD3-stimulated (in vitro) NOD thymocytes obtained at $8 \mathrm{wk}$, peripheral splenic T cells obtained at $8 \mathrm{wk}$ and $25 \mathrm{wk}$, and isletinfiltrating $\mathrm{T}$ cells examined at $25 \mathrm{wk}$ of age produce significantly higher levels of IL-4 when compared with the same subpopulations of cells isolated from control mice treated with a hamster Ig. Interestingly, shortly after termination of treatment with anti-CD28 mAb, thymic and splenic T cells showed a higher basal (no stimulation) production of IL-4 compared to cells obtained from age-matched (8-wk-old) control mice. With the exception of a 4.3-fold higher splenic T cell basal response in 8-wk-old anti-CD28 treated mice, no differences were detected between the proliferative responses of thymocyte, splenic $\mathrm{T}$ cells, and islet-infiltrating cells from 8 and 25-wk-old anti-CD28-treated NOD mice and those of the agematched controls (Fig. 5). The increase in basal T cell proliferation and IL-4 production may reflect the preferential costimulation of Th2 cells by anti-CD28 treatment in vivo. Indeed, we found that anti-CD28 treatment in vivo leads to an increased production of IgG1 (which reflects increased IL-4 pro- duction by $\mathrm{T}$ cells) rather than IgG2a anti-GAD67 antibodies (Fig. $6 \mathrm{~B}$ ). Moreover, the total number of splenic lymphocytes was increased about 1.9 -fold at $8 \mathrm{wk}$ of age and 1.7 -fold at $25 \mathrm{wk}$ of age in anti-CD28-treated NOD mice relative to that of control-treated mice (our unpublished data). These findings, together with our observation that anti-IL-4 treatment in vivo blocks the anti-CD28-induced protection from IDDM, support the idea that anti-CD28 treatment elicits the expansion and survival of IL-4-producing Th2 cells in NOD mice.

Anti-CD28 treatment did not significantly alter the level of IFN- $\gamma$ secretion by $\mathrm{T}$ cells from 8 -wk-old NOD mice when compared with that observed in age-matched control mice. Levels of IFN- $\gamma$ secretion by thymocytes and splenic T cells from 25-wk-old anti-CD28-treated NOD mice, however, were markedly reduced in comparison to those levels detected in control mice. These data demonstrate long-term downregulation of Th1 cell function, which may arise from the preferential activation of Th2 cells induced by CD28 costimulation during the inductive phase of the autoimmune process. The downregulation and/or functional deviation of Th1 cells towards a Th2 cell phenotype by IL-4 is more effective than and dominant over the inhibition of Th2 cell function by IL-12 (64-66). In- 


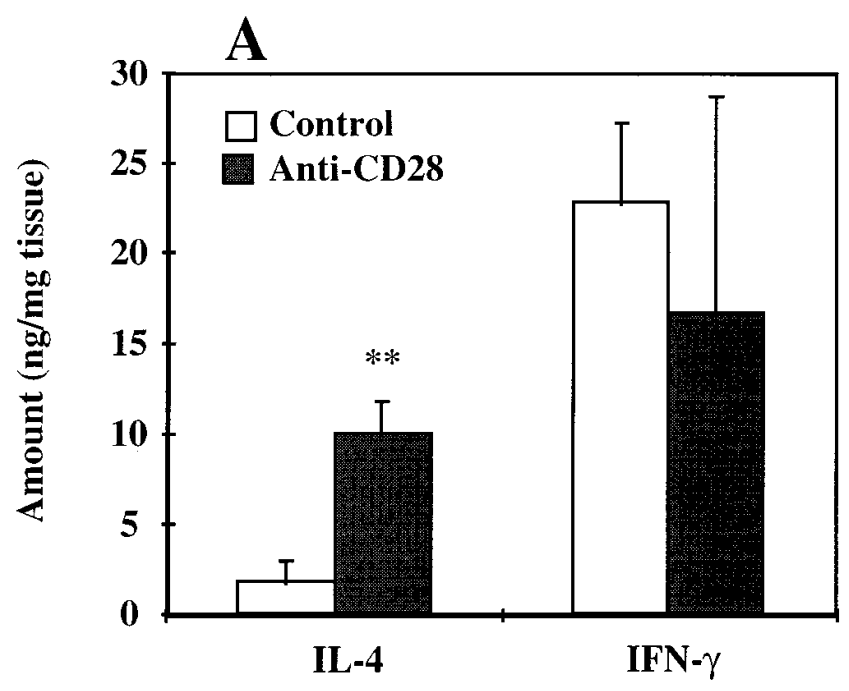

Cytokine

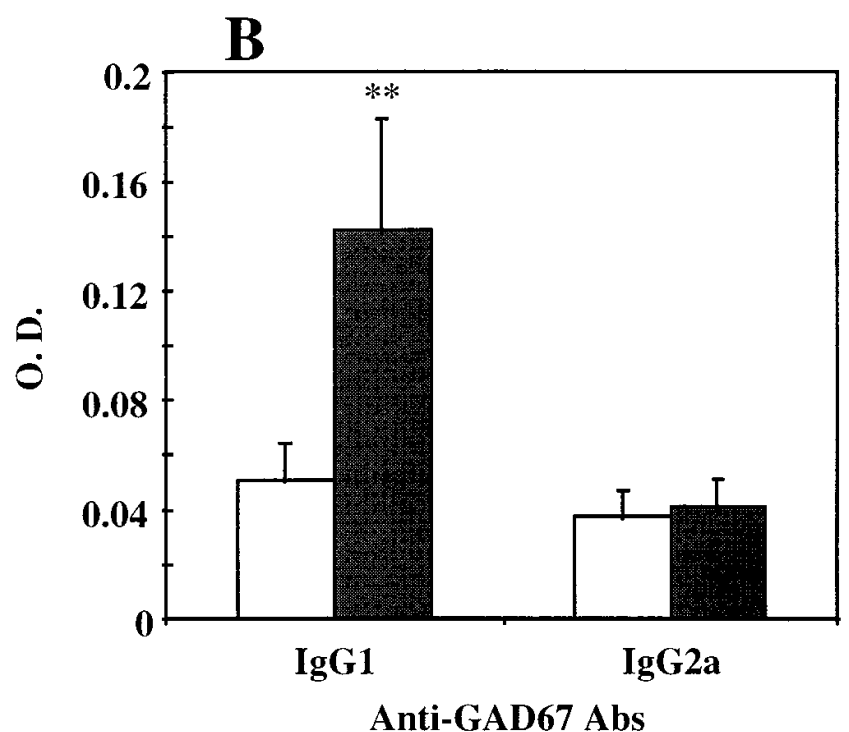

Figure 6. Intrapancreatic content of IL-4 and serum concentration of anti-GAD ${ }_{67}$ antibodies of the IgG1 isotype is enhanced after CD28 costimulation in vivo. $(A)$ NOD mice treated with either anti-CD28 $\mathrm{mAb}(n=7)$ or control hamster Ig $(n=5)$ were killed at $25 \mathrm{wk}$ of age, and the intrapancreatic IL- 4 and IFN- $\gamma$ concentrations were determined by ELISA. Values are expressed as mean $\mathrm{ng} / \mathrm{mg}$ of total protein extracted from pancreatic tissue samples. Comparison between means was performed by Student's $t$ test, and a $P$ value of $<0.05$ was chosen as the level of significance $(* * P<0.001)$. (B) Sera were collected and analyzed by ELISA for the presence of anti$\mathrm{GAD}_{67}$ antibodies of the IgG1 and IgG2a isotypes as described in Methods.

deed, when the development of a Th2 response is mediated by strong CD28 costimulation, the Th2 response is less sensitive to the inhibitory effects of IL-12 (67). Thus, our results agree with reports that IFN- $\gamma$-secreting Th1 cells potentiate the effector phase of insulitis, IFN- $\gamma$ is directly involved in $\beta$ cell destruction (68-71), and the early differentiation of naive $\mathrm{T}$ cells into $\mathrm{Th} 2$ cells is dependent on CD28 signaling $(33,36)$.

CD28 ligation promotes production of Th2 cytokines by naive murine T cells in an IL-4-dependent manner (72). Studies of the role of CD28 and B7 in the differentiation of Th1 and $\mathrm{Th} 2$ cells in a mouse model of Leishmania infection, however, show that CD28, although important, is not an absolute requirement for generation of a Th2 response (73). This result suggests that the mouse strain genetic background may contribute to Th1/Th2 phenotype polarization as much as costimulation. Nonetheless, our results of modulation of Th1/Th2 phenotype in NOD mice, together with the results of others obtained in either additional strains of autoimmune mice or in analyses of antigen-specific $\mathrm{T}$ cell responses in vitro $(33,36$, 72), illustrate a critical role for $\mathrm{CD} 28$ costimulation in $\mathrm{Th} 1 / \mathrm{Th} 2$ phenotype regulation. It is possible that the discrepancy between the results obtained in Leishmania-infected mice and those observed in autoimmune mice may be attributable to the high magnitude of the activation signal(s) delivered to T cells induced by Leishmania infection. The strength of this signal(s) may overcome any genetic deficiencies in T cell development as a result of compensatory mechanisms such as upregulation of other costimulatory surface receptors on $\mathrm{T}$ cells and/or the production of potent cytokines $(49,67,73)$, including IL-6, which has an important role in the control of Th2 cell differentiation (74).

Although anti-CD28 mAb treatment protects from IDDM, this treatment still allows for development of a nondestructive periinsulitis, and therefore does not interfere with migration of diabetogenic $\mathrm{T}$ cells to the pancreatic islets. Rather, anti-CD28 treatment appears to induce regulatory $\mathrm{T}$ cells in the pancreas to suppress islet $\beta$ cell destruction and progression to overt IDDM. Evidence in support of this notion is derived from assays of secretion of IL- 4 and IFN- $\gamma$ by infiltrating cells from mice treated with anti-CD28 or control Ig (Fig. 4) and from analyses of the levels of expression of these cytokines in the pancreas of anti-CD28 treated NOD mice at $25 \mathrm{wk}$ of age (Fig. 6). Note that intrapancreatic expression of IL-4 is significantly higher in anti-CD28 mAb-treated mice, whereas the expression of IFN- $\gamma$ remains essentially unaltered in these mice. Committed autoreactive cells, including Th1 cells, may accumulate in pancreatic islets, but the function of IL-4 predominates to inhibit IFN- $\gamma$-mediated $\beta$ cell damage.

Results of comparative FACS analyses of the phenotype and surface expression of various cell adhesion molecules and $\mathrm{T}$ cell activation markers in anti-CD28 mAb-treated and control IgG-treated NOD mice at 8-25 wk of age are consistent with our observation that anti-CD28 treatment does not block the migration of $\mathrm{T}$ cells to pancreatic islets. We found that the levels of expression of LFA-1, L-selectin, CD44, CD-69, ICAM-1, CD28, and B7-2 on splenic T cells did not differ significantly between anti-CD28-treated and control-treated NOD mice (our unpublished data). Similarly, no significant differences in expression of B7-1 and B7-2 were detected on splenic APCs (including B cells) from anti-CD28 versus control-treated NOD mice. In addition, the level of expression of CD28 on splenic T cells and of B7-1 and B7-2 on splenic APCs were the same in the NOD and control strains of mice. Lastly, the T $\left(\mathrm{CD}^{+}\right)$:B $\left(\mathrm{CD} 19^{+}\right)$and $\mathrm{CD} 4: \mathrm{CD} 8 \mathrm{~T}$ cell ratios in NOD mice were not altered by anti-CD28 treatment.

When splenic T cells from NOD mice ( $25 \mathrm{wk}$ of age) were transferred into NOD.Scid recipients, the transfer of IDDM was either prevented or significantly delayed if recipient mice received $\mathrm{T}$ cells from anti-CD28-treated donors (Fig. 7). All $(5 / 5)$ of the mice transferred with $\mathrm{T}$ cells from control $\mathrm{IgG}_{-}$ 


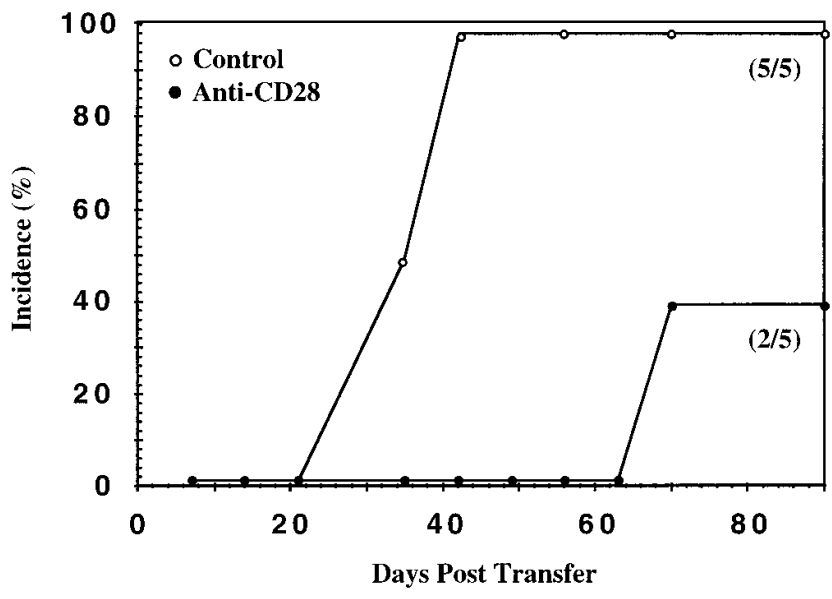

Figure 7. Adoptive transfer of $\mathrm{T}$ cells from anti-CD28 treated mice prevents/delays onset of IDDM in NOD.Scid recipients. Splenic T cells $\left(10^{7}\right)$ from prediabetic female NOD mice previously treated or untreated with anti-CD28 mAb were injected into female NOD.Scid mice ( $n=5 /$ group). The recipients were followed for a maximum of 12 wk after transfer, and BGL were monitored weekly.

treated mice became diabetic between 35-40 d after transfer, while only $2 / 5$ of the mice transferred with $T$ cells from antiCD28 treated animals developed diabetes by 90 d after transfer. These results are compatible with a previous report that Th1 cells, but not Th2 cells, can transfer IDDM to NOD.Scid recipients (11), and suggest that anti-CD28 mAb treatment activates regulatory $\mathrm{Th} 2$ that remain functional and prevent/reduce IDDM over a prolonged period. This effect may arise from the ability of CD28 ligation to sustain the proliferative response and enhance long-term survival of $\mathrm{T}$ cells by delivering a signal that protects from apoptosis through upregulation of survival factors such as Bcl- $\mathrm{x}_{\mathrm{L}}(75-77)$.

Concluding remarks. As previously suggested (78), CD28/ B7 interactions may differentially regulate $\mathrm{Th} 1 / \mathrm{Th} 2$ responses depending on the phase of the disease at which immune intervention is initiated. Blockade of CD28/B7 during the early phase of onset of an autoimmune disease preferentially blocks differentiation of the Th2 cell lineage and exacerbates the disease. Experiments conducted with CD28-deficient mice demonstrate that CD28 expression is required for predominant Th2 cell responses in an autoimmune environment $(32,33)$. Compatible with these findings, our results suggest that the activation of the CD28/B7 pathway during the early phase of onset of insulitis in NOD mice may stabilize a protective Th2-mediated environment in pancreatic islets. This type of environment appears to protect against a destructive insulitis and progression to IDDM. In contrast to other mAbs that protect NOD mice from IDDM, such as anti-CD4 and anti-CD3 mAbs $(79,80)$ the anti-CD28 mAb we used in this study appears to selectively activate a subset of regulatory Th2 cells by stimulating $\mathrm{T}$ cell clonal expansion in vivo, presumably by activating CD28 signaling and augmenting IL-2 and IL-4 secretion. AntiCD28 mAb treatment during the early inductive phase of diabetogenesis and much before the onset of disease therefore represents an effective means of immunostimulation. This treatment affords a promising type of immunotherapy for the IDDM prevention in individuals at high risk for the disease.
Our data are compatible with the notions that $(a)$ Th 2 cells require a higher threshold of activation than Th1 cells; $(b)$ in NOD mice, Th2 cells are deficient in their ability to receive this CD28-dependent signal from interacting APCs, and (c) this CD28 signal is requisite for activation of IL-4-producing NOD Th2 cells and protection from IDDM. We cannot, however, rule out the alternate possibility that NOD APCs may not provide an appropriate or sufficient CD28 costimulation signal during the inductive phase of IDDM development. Further experimentation is required to discern between these possibilities. In conclusion, our results indicate that augmenting costimulation at an early age can completely prevent development of a spontaneous organ-specific autoimmune disease.

\section{Acknowledgments}

We thank Drs. L. Schultz, J. Allison, J. Bluestone, and W.E. Paul for their kind gifts of reagents, J. Cator, D. Goodale, and C. Richardson for maintaining our mouse colony, and all members of our laboratory for their valuable advice and encouragement. We also thank Anne Leaist for her valuable assistance in the preparation of this manuscript.

This work is supported by grants from the Juvenile Diabetes Foundation International, the Medical Research Council of Canada/ Juvenile Diabetes Foundation International Diabetes Interdisciplinary Research Program, the Helen M. Armstrong grant of the Canadian Diabetes Association to T.L. Delovitch, a grant from the Faculty of Medicine, University of Western Ontario to S. Chakrabarti, and by the Department of Veterans Affairs and National Institutes of Health grant HL31693 to S.W. Chensue. G. Arreaza and A. Jaramillo are recipients of a postdoctoral fellowship from the Canadian Diabetes Association. B.M. Gill and M.J. Rapoport are recipients of a postdoctoral fellowship from the Juvenile Diabetes Foundation International. K.B. Laupland and D. Hardy are recipients of summer studentships from the Juvenile Diabetes Foundation International.

\section{References}

1. Bach, J.F. 1994. Insulin-dependent diabetes mellitus as an autoimmune disease. Endocr. Rev. 15:516-542.

2. Atkinson, M.A., and N.K. Maclaren. 1994. Mechanisms of disease: the pathogenesis of insulin-dependent diabetes mellitus. N. Engl. J. Med. 331:14281436.

3. Tisch, R., and H. McDevitt. 1996. Insulin-dependent diabetes mellitus. Cell. 85:291-297.

4. Bendelac, A., C. Carnaud, C. Boitard, and J.F. Bach. 1987. Syngeneic transfer of autoimmune diabetes from NOD mice to healthy neonates. Requirement for both L3T4+ and Lyt-2+ T cells. J. Exp. Med. 166:823-832.

5. Christianson, S.W., L.D. Shultz, and E.H. Leiter. 1993. Adoptive transfer of diabetes into immunodeficient NOD-scid/scid mice: Relative contributions of CD4+ and CD8 + T cells from diabetic versus prediabetic NOD.NON-Thy1a donors. Diabetes. 42:44-55.

6. Rohane, P.W., A. Shimada, D.T. Kim, C.T. Edwards, B. Charlton, L.D Shultz, and C.G. Fathman. 1995. Islet-infiltrating lymphocytes from prediabetic NOD mice rapidly transfer diabetes to NOD-scid/scid mice. Diabetes. 44:550-554.

7. Haskins, K., and M. McDuffie. 1990. Acceleration of diabetes in young NOD mice with a CD4+ islet specific T cell clone. Science (Wash. DC). 249: 1433-1436.

8. Wang, Y., O. Pontesili, R.G. Gill, F.G. La Rosa, and K.J. Lafferty. 1991. The role of $\mathrm{CD}^{+}$and $\mathrm{CD}^{+} \mathrm{T}$ cells in the destruction of islets grafts by spontaneously diabetic mice. Proc. Natl. Acad. Sci. USA. 88:527-532.

9. Rabinovitch, A. 1994. Immunoregulatory and cytokine imbalances in the pathogenesis of IDDM: therapeutic intervention by immunostimulation? Diabetes. 43:613-621.

10. Liblau, R.S., S.M. Singer, and H.O. McDevitt. 1995. Th1 and Th2 CD4+ $\mathrm{T}$ cells in the pathogenesis of organ-specific autoimmune diseases. Immunol. Today. 16:34-38.

11. Katz, J.D., C. Benoist, and D. Mathis. 1995. T helper cell subsets in insulin-dependent diabetes. Science (Wash. DC). 268:1185-1188.

12. Zipris, D., A.H. Lazarus, A.R. Crow, M. Hadzija, and T.L. Delovitch. 1991. Defective thymic T cell activation by concanavalin A and anti-CD3 in autoimmune nonobese diabetic mice. J. Immunol. 146:3763-3771. 
13. Rapoport, M.J., A. Jaramillo, D. Zipris, A.H. Lazarus, D.V. Serreze, E.H. Leiter, P. Cyopick, J.S. Danska, and T.L. Delovitch. 1993. Interleukin 4 reverses $\mathrm{T}$ cell proliferative unresponsiveness and prevents the onset of diabetes in nonobese diabetic mice. J. Exp. Med. 178:87-99.

14. Jaramillo, A., B.M. Gill, and T.L. Delovitch. 1994. Insulin-dependent diabetes mellitus in the non-obese diabetic mouse: a disease mediated by $\mathrm{T}$ cell anergy? Life Sci. 55:1163-1177.

15. Berman, M.A., C.I. Sandborg, Z. Wang, K.L. Imfeld, F. Zaldivar, V. Dadufalza, and B.A. Buckingham. 1996. Decreased IL-4 production in new onset type I insulin-dependent diabetes mellitus. J. Immunol. 157:4691-4696.

16. Mueller, R., T. Krahl, and N. Sarvetnick. 1996. Pancreatic expression of interleukin-4 abrogates insulitis and autoimmune diabetes in nonobese diabetic (NOD) mice. J. Exp. Med. 184:1093-1099.

17. Arreaza, G.A., M.J. Cameron, and T.L. Delovitch. 1996. Interleukin-4: potential immunoregulatory agent in therapy of insulin-dependent diabetes mellitus. Clin. Immunother. 4:251-260.

18. June, C.H., J.A. Bluestone, L.M. Nadler, and C.B. Thompson. 1994. The B7 and CD28 receptor families. Immunol. Today. 15:321-331.

19. Bluestone, J.A. 1995. New perspectives of CD28-B7-mediated T cell costimulation. Immunity. 2:555-559.

20. Thompson, C.B. 1995. Distinct roles for the costimulatory ligands B7-1 and B7-2 in T helper cell differentiation? Cell. 81:979-982.

21. Jenkins, M.K., D. Mueller, and R.H. Schwartz. 1991. Induction and maintenance of anergy in mature T cells. Adv. Exp. Med. Biol. 292:167-176.

22. Seder, R.A., R.N. Germain, P.S. Linsley, and W.E. Paul. 1994. CD28mediated costimulation of interleukin 2 (IL-2) production plays a critical role in T cell priming for IL-4 and interferon- $\gamma$ production. J. Exp. Med. 179:299-304.

23. Linsley, P.S., E.A. Clark, and J.A. Ledbetter. 1990. T cell antigen CD28 mediates adhesion with B cells by interacting with activation antigen B7/BB-1. Proc. Natl. Acad. Sci. USA. 87:5031-5035.

24. Freeman, G.J., F. Borriello, R.J. Hodes, H. Reiser, J.G. Gribben, J.W. $\mathrm{Ng}$, J. Kim, J.M. Goldberg, K. Hathcock, G. Lazlo et al. 1993. Murine B7-2: an alternative CTLA-4 counter-receptor that costimulates $\mathrm{T}$ cell proliferation and interleukin 2 production. J. Exp. Med. 178:2185-2192.

25. Lenschow, D.L., G.H. Su, L.A. Zuckerman, N. Nabavi, C.L. Jellis, G.S. Gray, J. Miller, and J.A. Bluestone. 1993. Expression and functional significance of an additional ligand for CTLA-4. Proc. Natl. Acad. Sci. USA. 90: 11054-11058.

26. Freeman, G.J., V.A. Boussiotis, A. Anumanthan, G.M. Bernstein, X.-Y. Ke, P.D. Rennert, G.S. Gray, J.G. Gribben, and L.M. Nadler. 1995. B7-1 and B7-2 do not deliver identical costimulatory signals, since B7-2 but not B7-1 preferentially costimulates the initial production of IL-4. Immunity. 2:523-532.

27. Kuchroo, V.K., M.P. Das, J.A. Brown, A.M. Ranger, S.S. Zamvil, R.A. Sobel, H.L. Weiner, N. Nabavi, and L.H. Glimcher. 1995. B7-1 and B7-2 costimulatory molecules activate differentially the Th1/Th2 developmental pathways: application to autoimmune disease therapy. Cell. 80:707-718.

28. Lenschow, D., S. Ho, H. Sattar, L. Rhee, G. Gray, N. Nabavi, K. Herold, and J.A. Bluestone. 1995. Differential effects of anti-B7-1 and anti-B7-2 monoclonal antibody treatment on the development of diabetes in the nonobese diabetic mouse. J. Exp. Med. 181:1145-1155.

29. Corry, D.B., S.L. Reiner, P.S. Linsley, and R.M. Locksley. 1994. Differential effects of blockade of CD28-B7 on the development of Th1 or Th2 effector cells in experimental Leishmaniasis. J. Immunol. 153:4142-4148.

30. Lu, P., X.D. Zhou, S.J. Chen, M. Moorman, S.C. Morris, F.D. Finkelman, P. Linsley, J.F. Urban, and W.C. Gause. 1994. CTLA-4 ligands are required to induce an in vivo interleukin 4 reponse to a gastrointestinal nematode parasite. J. Exp. Med. 180:693-698.

31. Ronchese, F., B. Hausmann, S. Hubele, and P. Lane. 1994. Mice transgenic for a soluble form of murine CTLA-4 show enhanced expansion of antigen-specific $\mathrm{CD}^{+} \mathrm{T}$ cells and defective antibody production in vivo. J. Exp. Med. 179:299-304

32. Bachmaier, K., C. Pummerer, A. Shahinian, J. Ionescu, N. Neu, T. Mak, and J.M. Penninger. 1996. Induction of autoimmunity in the absence of CD28. J. Immunol. 157:1752-1757.

33. Lenschow, D.J., K.C. Herold, L. Rhee, B. Patel, A. Koons, H.-Y. Qin, E. Fuchs, B. Singh, C.B. Thompson, and J.A. Bluestone. 1996. CD28/B7 regulation of Th1 and Th2 subsets in the development of autoimmune diabetes. Immunity. 5:285-293.

34. King, C.L., R.J. Stupi, N. Craighead, C.H. June, and G. Thyphronitis. 1995. CD28 activation promotes Th2 subset differentiation by human CD $4^{+}$ cells. Eur. J. Immunol. 25:587-595

35. Kalinski, P., C.M.U. Hilkens, E.A. Wierenga, T.C. van der Pouw-Kraan, R. van Lier, J.D. Bos, M.L. Kapsenberg, and F.G.M. Snidjewint. 1995. Functional maturation of human naive $\mathrm{T}$ helper cells in the absence of accessory cells. Generation of IL-4 producing cells does not require exogenous IL-4. J. Immunol. 154:3753-3760.

36. Webb, L., and M. Feldman. 1995. Critical role of CD28/B7 costimulation in the development of human Th2 cytokine-producing cells. Blood. 86: 3479-3486.

37. Kawamura, T., and M. Furue. 1995. Comparative analysis of B7-1 and B7-2 expression in Langerhans cells: differential regulation by T helper type 1 and T helper type 2 cytokines. Eur. J. Immunol. 25:1913-1917.
38. Stack, R.M., D.J. Lenschow, J.S. Gray, J.A. Bluestone, and F.W. Fitch. 1994. IL-4 treatment of small splenic B cells induces costimulatory molecules B7-1 and B7-2. J. Immunol. 152:5723-5733.

39. Serreze, D.V., and E.H. Leiter. 1988. Defective activation of T suppressor cell function in nonobese diabetic mice. Potential relation to cytokine deficiencies. J. Immunol. 140:3801-3807.

40. Serreze, D.V., H.R. Gaskins, and E.H. Leiter. 1993. Defects in the differentiation and function in antigen presenting cells in NOD/Lt mice. J. Immunol. 150:2534-2540.

41. Gross, J.A., E. Callas, and J.P. Allison. 1992. Identification and distribution of the costimulatory receptor CD28 in the mouse. J. Immunol. 149:380-387.

42. Ohara, J., and W.E. Paul. 1985. Production of monoclonal antibody to and molecular characterization of B cell stimulatory factor 1. Nature (Lond.). 315:333-336.

43. Gillis, S., and K.A. Smith. 1977. Long term culture of tumour-specific cytotoxic T cells. Nature (Lond.). 268:154-156.

44. Li, J.H., J. Ohara, C. Watson, W. Tsang, and W.E. Paul. 1989. Derivation of a T cell line that is highly responsive to IL-4 and IL-2 (CT.4R) and of an IL-2 hyporesponsive mutant of that line (CT.4S). J. Immunol. 142:800-807.

45. Mosmann, T.R., H. Cherwinski, M.W. Bond, M.A. Giedlin, and R.L. Coffman. 1986. Two types of murine helper cell clone. I. Definition according to profiles of lymphokine activities and secreted proteins. J. Immunol. 136 $2348-2357$.

46. Chensue, S.W., K.S. Warmington, N.W. Lukacs, P.M. Lincoln, M.D. Burdick, R.M. Strieter, and S.L. Kunkel. 1995. Monocyte chemotactic protein expression during schistosome egg granuloma formation. Am. J. Pathol. 146: $130-138$.

47. Elliot, J.F., H.-Y. Qin, S. Bhatti, D.K. Smith, R.K. Singh, T. Dillon, J. Lauzon, and B. Singh. 1994. Immunization with the larger isoform of mouse glutamic acid decarboxylase prevents autoimmune diabetes in NOD mice. Diabetes. 43:1494-1499.

48. McArthur, J.G., and D.H. Raulet. 1993. CD28-induced costimulation of T helper type 2 cells mediated by induction of responsiveness to interleukin 4.J. Exp. Med. 178:1645-1653.

49. Gause, W.C., M. Halvorson, L. Pin, R. Greenwald, P. Linsley, J.F. Urban, and F.D. Finkelman. 1997. The function of costimulatory molecules and the development of IL-4-producing T cells. Immunol. Today. 18:115-120.

50. Gombert, J.M., E. Tancrede-Bohin, M. Dy., C. Carnaud, and J.F. Bach. 1996. Early quantitative and functional deficiency of $\mathrm{NK} 1^{+}$-like thymocytes in the NOD mouse. Eur. J. Immunol. 26:2989-2998.

51. Holter, W., O. Madjic, F.S. Kalthoff, and W. Knapp. 1992. Regulation of interleukin-4 production in human mononuclear cells. Eur. J. Immunol. 22: 2765-2767.

52. de Boer, M., A. Kasran, J. Kwekkeboom, H. Walter, P. Vandenberghe, and J.L. Ceuppens. 1993. Ligation of B7 with CD28/CTLA-4 on T cells results in CD40 ligand expression, interleukin-4 secretion, and efficient help for antibody production by B cells. Eur. J. Immunol. 23:3120-3125.

53. Tanaka, T., S.Z. Ben-Sasson, and W.E. Paul. 1991. IL-4 increases IL-2 production by $\mathrm{T}$ cells in response to accessory cell-independent stimuli. J. Immunol. 146:3831-3839.

54. Rapoport, M.J., A.H. Lazarus, A. Jaramillo, E. Speck, and T.L. Delovitch. 1993. Deficient $\mathrm{T}$ cell receptor regulated $\mathrm{p} 21^{\text {ras }}$ activation mediates thymic $\mathrm{T}$ cell anergy and may predispose to diabetes in autoimmune NOD mice. $J$. Exp. Med. 177:1221-1226.

55. Boitard, C., R. Yasunami, M. Dardenne, and J.F. Bach. 1989. T cellmediated inhibition of the transfer of autoimmune diabetes in NOD mice. $J$. Exp. Med. 169:1669-1680.

56. Shehadeh, N.N., F. LaRosa, and K.J. Lafferty. 1993. Altered cytokine activity in adjuvant inhibition of autoimmune diabetes. J. Autoimmun. 6:291-300.

57. Pennline, K.J., E. Roque-Gaffney, and M. Monahan. 1994. Recombinant human IL-10 prevents the onset of diabetes in the nonobese diabetic mouse. Clin. Immunol. Immunopathol. 71:169-175.

58. Shi, Y., L.G. Radvanyi, A. Sharma, P. Shaw, D.R. Green, R.G. Miller, and G.B. Mills. 1995. CD28-mediataed signaling in vivo prevents activationinduced apoptosis in the thymus and alters peripheral lymphocyte homeostasis. J. Immunol. 155:1829-1837.

59. Wang, R., F. Qiding, L. Zhang, L. Radvany, A. Sharma, N. NobenTrauth, G.B. Mills, and Y. Shi. 1997. CD28 ligation prevents bacterial toxininduced septic shock in mice by inducing IL-10 expression. J. Immunol. 158: 2856-2861.

60. Krummel, M.F., and J.P. Allison. 1995. CD28 and CTLA-4 deliver opposing signals which regulate the response of $\mathrm{T}$ cells to stimulation. J. Exp. Med. 182:459-465.

61. Delovitch, T.L., A. Jaramillo, M.J. Rapoport, K. Laupland, D. Zipris, S Smith, D. Kelvin, and B.M. Gill. 1995. Anti-inflammatory role of IL-4 and Th2 cells in the protection against IDDM. In Diabetes 1994. S. Baba and T. Kaneko, editors. Elsevier Science B.V., Amsterdam. 203-209.

62. Seder, R.A., and W.E. Paul. 1994. Acquisition of lymphokine-producing phenotype by CD4 ${ }^{+}$T cells. Annu. Rev. Immunol. 12:635-673.

63. Ranger, A.M., M.P. Das, V.K. Kuchroo, and L.H. Glimcher. 1996. B7-2 (CD86) is essential for the development of IL-4-producing T cells. Int. Immunol. 8:1549-1560. 
64. Perez, V.L., J.A. Lederer, A.H. Lichtman, and A.K. Abbas. 1995. Stability of Th1 and Th2 populations. Int. Immunol. 7:869-875.

65. Szabo, S.J., N.G. Jacobson, A.S. Dighe, U. Gubler, and K.M. Murphy. 1995. Developmental commitment to the Th2 lineage by extinction of IL-12 signaling. Immunity. 2:665-675.

66. Murphy, E., K. Shibuya, N. Hosken, P. Openshaw, V. Maino, K. Davis, K. Murphy, and A. O'Garra. 1996. Reversibility of T helper 1 and 2 populations is lost after long term stimulation. J. Exp. Med. 183:901-913.

67. Chu, N.R., M.A DeBenedette, B.J. Stiernholm, B.H. Barber, and T.H. Watts. 1997. Role of IL-12 and 4-1BB ligand in cytokine production by CD28 ${ }^{+}$ and CD28- T cells. J. Immunol. 158:3081-3089.

68. Pilstrom, B., L. Bjork, and J. Bohme. 1995. Demonstration of a Th1 cytokine profile in the late phase of NOD insulitis. Cytokine. 7:806-814.

69. Rabinovitch, A., W. Suarez, O. Sorensen, C. Bleackley, and R.F. Power. 1995. IFN- $\gamma$ gene expression in pancreatic islet-infiltrating mononuclear cells correlates with autoimmune diabetes in nonobese diabetic mice. J. Immunol. 154:4874-4882

70. Herold, K.C., V. Vezys, Q. Sun, D. Viktora, E. Seung, S. Reiner, and D.R. Brown. 1996. Regulation of cytokine production during development of autoimmune diabetes induced with multiple low doses of streptozotocin. J. Immunol. 156:3521-3527.

71. Shimada, A., P. Rohane, C.G. Fathman, and B. Charlton. 1996. Pathogenic and protective roles of CD45RB low CD4+ cells correlate with cytokine profiles in the spontaneously autoimmune diabetic mouse. Diabetes. 45:71-78.

72. Rulifson, I.C., A.I. Sperling, P.E Fields, F.W. Fitch, and J.A. Bluestone. 1997. CD28 costimulation promotes the production of Th2 cytokines. J. Immu- nol. 158:658-665.

73. Brown, D.R., J.M. Green, N.H. Moskowitz, M. Davis, C.B. Thompson, and S.L. Reiner. 1996. Limited role of CD28-mediated signals in T helper subset differentiation. J. Exp. Med. 184:803-810.

74. Rincón, M.J., J. Anguita, T. Nakamura, E. Fikrig, and R.A. Flavell. 1997. IL-6 directs the differentiation of IL-4-producing CD4+ T cells. J. Exp. Med. 185:461-469.

75. Boise, L.H., A.J. Minn, P.J. Noel, C.H. June, M.A. Accavitti, T. Lindsten, and C.B. Thompson. 1995. CD28 costimulation can promote survival by enhancing the expression of Bcl- $\mathrm{x}_{\mathrm{L}}$. Immunity. 3:87-98.

76. Sperling, A., J.A. Auger, B.D. Ehst, I.C. Rulifson, C.B. Thompson, and J.A. Bluestone. 1996. CD28/B7 interactions deliver a unique signal to naive T cells that regulates cell survival but not early proliferation. J. Immunol. 157: 3909-3917.

77. Radvanyi, L.G., Y. Shi, H. Vaziri, A. Sharma, R. Dhala, G.B. Mills, and R. Miller. 1996. CD28 costimulation inhibits TCR-induced apoptosis during a primary T cell response. J. Immunol. 156:1788-1798.

78. Lenschow, D.J., T.L. Walunas, and J.A. Bluestone. 1996. CD28/B7 system T cell costimulation. Annu. Rev. Immunol. 14:233-258.

79. Shizuru, J.A., C. Taylor-Edwards, B.A. Banks, A.K. Gregory, and C.G. Fathman. 1988. Immunotherapy of the non-obese diabetic mouse; treatment with an antibody to T helper lymphocytes. Science (Wash. DC). 240:659-662.

80. Chatenoud, L., E. Thervet, J. Primo, and J.F. Bach. 1994. Anti-CD3 antibody induces long-term remission of overt autoimmunity in nonobese diabetic mice. Proc. Natl. Acad. Sci. USA. 91:123-127. 